\title{
Reviews and syntheses: Soil resources and climate jointly drive variations in microbial biomass carbon and nitrogen in China's forest ecosystems
}

\author{
Z. H. Zhou ${ }^{1, *}$ and C. K. Wang ${ }^{1, *}$ \\ ${ }^{1}$ Center for Ecological Research, Northeast Forestry University, 26 Hexing Road, Harbin 150040, China \\ *These authors contributed equally to this work.
}

Correspondence to: C. K. Wang (wangck-cf@nefu.edu.cn)

Received: 28 February 2015 - Published in Biogeosciences Discuss.: 16 July 2015

Revised: 21 September 2015 - Accepted: 23 October 2015 - Published: 26 November 2015

\begin{abstract}
Microbial metabolism plays a key role in regulating the biogeochemical cycle of forest ecosystems, but the mechanisms driving microbial growth are not well understood. Here, we synthesized 689 measurements on soil microbial biomass carbon $\left(\mathrm{C}_{\mathrm{mic}}\right)$ and nitrogen $\left(\mathrm{N}_{\text {mic }}\right)$ and related parameters from 207 independent studies published up to November 2014 across China's forest ecosystems. Our objectives were to (1) examine patterns in $\mathrm{C}_{\text {mic }}, \mathrm{N}_{\text {mic }}$, and microbial quotient (i.e., $\mathrm{C}_{\text {mic }} / \mathrm{C}_{\text {soil }}$ and $\mathrm{N}_{\text {mic }} / \mathrm{N}_{\text {soil }}$ rates) by climate zones and management regimes for these forests; and (2) identify the factors driving the variability in the $C_{m i c}$, $\mathrm{N}_{\text {mic }}$, and microbial quotient. There was a large variability in $\mathrm{C}_{\text {mic }}\left(390.2 \mathrm{mg} \mathrm{kg}^{-1}\right), \mathrm{N}_{\text {mic }}\left(60.1 \mathrm{mg} \mathrm{kg}^{-1}\right), \mathrm{C}_{\text {mic }}: \mathrm{N}_{\text {mic }}$ ratio $(8.25), \mathrm{C}_{\text {mic }} / \mathrm{C}_{\text {soil }}$ rate $(1.92 \%)$, and $\mathrm{N}_{\text {mic }} / \mathrm{N}_{\text {soil }}$ rate $(3.43 \%)$ across China's forests. The natural forests had significantly greater $\mathrm{C}_{\text {mic }}\left(514.1 \mathrm{mg} \mathrm{kg}^{-1}\right.$ vs. $\left.281.8 \mathrm{mg} \mathrm{kg}^{-1}\right)$ and $\mathrm{N}_{\text {mic }}\left(82.6 \mathrm{mg} \mathrm{kg}^{-1}\right.$ vs. $\left.39.0 \mathrm{mg} \mathrm{kg}^{-1}\right)$ than the planted forests, but had less $\mathrm{C}_{\text {mic }}: \mathrm{N}_{\text {mic }}$ ratio (7.3 vs. 9.2) and $\mathrm{C}_{\text {mic }} / \mathrm{C}_{\text {soil }}$ rate $(1.7 \%$ vs. $2.1 \%)$. Soil resources and climate together explained $24.4-40.7 \%$ of these variations. The $\mathrm{C}_{\text {mic }}: \mathrm{N}_{\text {mic }}$ ratio declined slightly with $\mathrm{C}_{\text {soil }}: \mathrm{N}_{\text {soil }}$ ratio, and changed with latitude, mean annual temperature and precipitation, suggesting a plasticity of microbial carbonnitrogen stoichiometry. The $\mathrm{C}_{\text {mic }} / \mathrm{C}_{\text {soil }}$ rate decreased with $\mathrm{C}_{\text {soil }}: \mathrm{N}_{\text {soil }}$ ratio, whereas the $\mathrm{N}_{\text {mic }} / \mathrm{N}_{\text {soil }}$ rate increased with $\mathrm{C}_{\text {soil }}: \mathrm{N}_{\text {soil }}$ ratio; the former was influenced more by soil resources than by climate, whereas the latter was influenced more by climate. These results suggest that soil microbial assimilation of carbon and nitrogen are jointly driven by soil re-
\end{abstract}

sources and climate, but may be regulated by different mechanisms.

\section{Introduction}

Microbial metabolism is closely coupled with ecological processes such as decomposition, nutrient cycling, and rhizosphere symbiosis, and hence plays a key role in regulating the biogeochemical cycle of terrestrial ecosystems (Chapin et al., 2011). Microbial communities convert soil organic carbon $\left(\mathrm{C}_{\text {soil }}\right)$ and nitrogen $\left(\mathrm{N}_{\text {soil }}\right)$ into microbial biomass and release $\mathrm{CO}_{2}$ to the atmosphere, mineralize soil organic matter (SOM) and nutrients, and thus control energy and material flows between trophic levels (Miltner et al., 2012; Sinsabaugh et al., 2013). Although soil microbial biomass carbon $\left(\mathrm{C}_{\text {mic }}\right)$ and nitrogen $\left(\mathrm{N}_{\text {mic }}\right)$ only account for $0.9-6.5 \%$ of $\mathrm{C}_{\text {soil }}$ and 1.7-8.1\% of $\mathrm{N}_{\text {soil }}$, respectively (Xu et al., 2013), microbial decomposition of SOM releases about half of the total soil $\mathrm{CO}_{2}$ efflux (Wang and Yang, 2007). Microbes also provide supplementary nutrients for the plants particularly in nutrient-limited ecosystems (Singh et al., 1989) because of the dichotomous seasonality between microbial biomass and soil nutrient availability (Kaiser et al., 2011). Therefore, understanding soil microbial metabolism and its feedback to climate change is critical in carbon cycling studies (Davidson and Janssens, 2006; Singh et al., 2010) especially in forest ecosystems that contain more than $70 \%$ of the global $\mathrm{C}_{\text {soil }}$ storage (Jandl et al., 2007). 
Recently, Xu et al. (2013) synthesized the global microbial biomass data of terrestrial ecosystems, of which only about $24 \%$ were of forest ecosystems mainly from North America and Europe. China has diverse geographic and environmental conditions, including a latitudinal gradient from boreal to tropical climate zones, a longitudinal gradient from arid deserts to humid forests, and an altitudinal ladder-like topography from the east to the west, which allow various forests to exist (Fang et al., 2012; Yang et al., 2014). Research on the forest soil microbes in China had lagged behind many regions in the world, but has been catching up rapidly since 2000 . During the past 15 years, large amounts of data on microbial biomass have been produced but not synthesized yet. Synthetic analyses of these data will help to understand the patterns and environmental controls of soil microbial biomass.

Soil resources saliently influence microbial growth (He et al., 2014; Jagadamma et al., 2014; Kaiser et al., 2014), because $\mathrm{C}_{\text {soil }}$ and $\mathrm{N}_{\text {soil }}$ are the fundamental sources of energy and nutrients for microbial metabolism (Wardle, 1992; $\mathrm{Xu}$ et al., 2014; Spohn, 2015). Soil microbial quotient (i.e., $\mathrm{C}_{\text {mic }} / \mathrm{C}_{\text {soil }}$ and $\mathrm{N}_{\text {mic }} / \mathrm{N}_{\text {soil }}$ rates) is an important index of carbon assimilation of microorganisms (Xu et al., 2014), and also a sensitive indicator of soil biological responses to environmental changes (Sparling, 1992). To date, however, it is not conclusive how soil substrates control microbial metabolic processes. For example, Xu et al. (2014), using field data and modeling simulation, indicated that soil microbial quotient decreased exponentially with the $\mathrm{C}_{\text {soil }}: \mathrm{N}_{\text {soil }}$ ratio at a biome-level. On the other hand, Spohn (2015), based on laboratory incubation data, reported that microbial metabolic quotient (i.e., respiration rate per unit microbial biomass) linearly increased with the litter $\mathrm{C}: \mathrm{N}$ ratio but decreased with the litter nitrogen concentration. Such diverse relationships between soil resources and microbial metabolism may be associated with environmental conditions and research scales, because the translocation of soil resources involves a series of biological activities and physical diffusion that are constrained by soil temperature and moisture regimes especially in frozen or arid harsh environment or seasons (Jefferies et al., 2010; Edwards and Jefferies, 2013).

At a large scale, geographic climate is the primary driver of vegetation communities (Drenovsky et al., 2010). Vegetation controls $\mathrm{C}_{\text {soil }}$ inputs, alters soil habitats by modifying rhizospheric activities and elemental stoichiometry, and eventually influences microbial composition and metabolism (Paterson et al., 2007; Bell et al., 2014). Additionally, forest disturbances change soil and vegetation characteristics, which in turn alter microbial biochemical processes (Holden and Treseder, 2013). Of the diverse influencing factors, it is not clear which are the major drivers of the variability in soil microbial biomass (Wardle, 1998; Xu et al., 2013).

In this study, we retrieved peer-reviewed papers on microbial biomass in China's forest ecosystems published up to November 2014. The database included 689 measurements from 207 independent studies (Table S1 in the Supplement) that covered all the climate zones (frigid highland, cool temperate, warm temperate, temperate desert, subtropical/tropical zones) and management regimes (natural vs. planted forests; Fig. 1). The objectives of this synthesis were to (1) examine patterns in $\mathrm{C}_{\mathrm{mic}}, \mathrm{N}_{\mathrm{mic}}$, and microbial quotient by climate zones and management regimes for China's forest ecosystems; and (2) identify the factors driving the variability in the $\mathrm{C}_{\text {mic }}, \mathrm{N}_{\text {mic }}$, and microbial quotient. We hypothesized that (1) $\mathrm{C}_{\mathrm{mic}}, \mathrm{N}_{\mathrm{mic}}$, and microbial quotient vary with climate zones and management regimes because of different quality and quantity of soil resources and environmental conditions involved; and (2) the variability in $\mathrm{C}_{\text {mic }}$ and $\mathrm{N}_{\text {mic }}$ are jointly driven by soil resources and climate (a proxy of soil temperature and moisture regimes).

\section{Methods}

\subsection{Data collection}

We collected the data on soil microbial biomass of China's forest ecosystems published up to November 2014. The literature retrieval was conducted through the China National Knowledge Infrastructure (CNKI, http://www.cnki.net; almost all studies indexed are conducted in China) and the Web of Science (http://apps.webofknowledge.com) online databases using "soil microbial", "forest" and "China" or "Chinese" as the key words. To enhance the cross-study comparability, the original papers were further screened by the following criteria: (1) the studies must contain corresponding $\mathrm{C}_{\text {soil }}$ or SOM and $\mathrm{N}_{\text {soil }}$ data. The SOM values were converted into $\mathrm{C}_{\mathrm{soil}}$ values using the Bemmelen index (0.58, Mann, 1986). (2) Following previous synthesized studies (e.g., Don et al., 2011), the data with anthropogenic disturbances or management activities in recent years $(<7$ years) were excluded. (3) Only the measurements from the control or untreated plots were included if a manipulated experiment was employed. And (4) the data on $\mathrm{C}_{\text {mic }}$ and $\mathrm{N}_{\text {mic }}$ determined only with the chloroform fumigation-extraction method were included, but the conversion factors were ignored due to lacking detailed description in the original literature. To our knowledge, there were no papers published before 2000 reporting China's soil microbial biomass that were measured with the chloroform fumigation-extraction method. Eventually, 689 measurements from 207 peer-reviewed papers met the criteria above and were included in this synthesis (Table S1). The data set covered the forest regions across China, divergent in climate zones and management regimes (Fig. 1).

We also obtained corresponding data on the geographic locations (latitude, longitude), climate conditions (mean annual temperature (MAT), mean annual precipitation; MAP), soil properties (bulk density), and vegetation characteristics (forest type, management regime). Unlike previous syntheses 


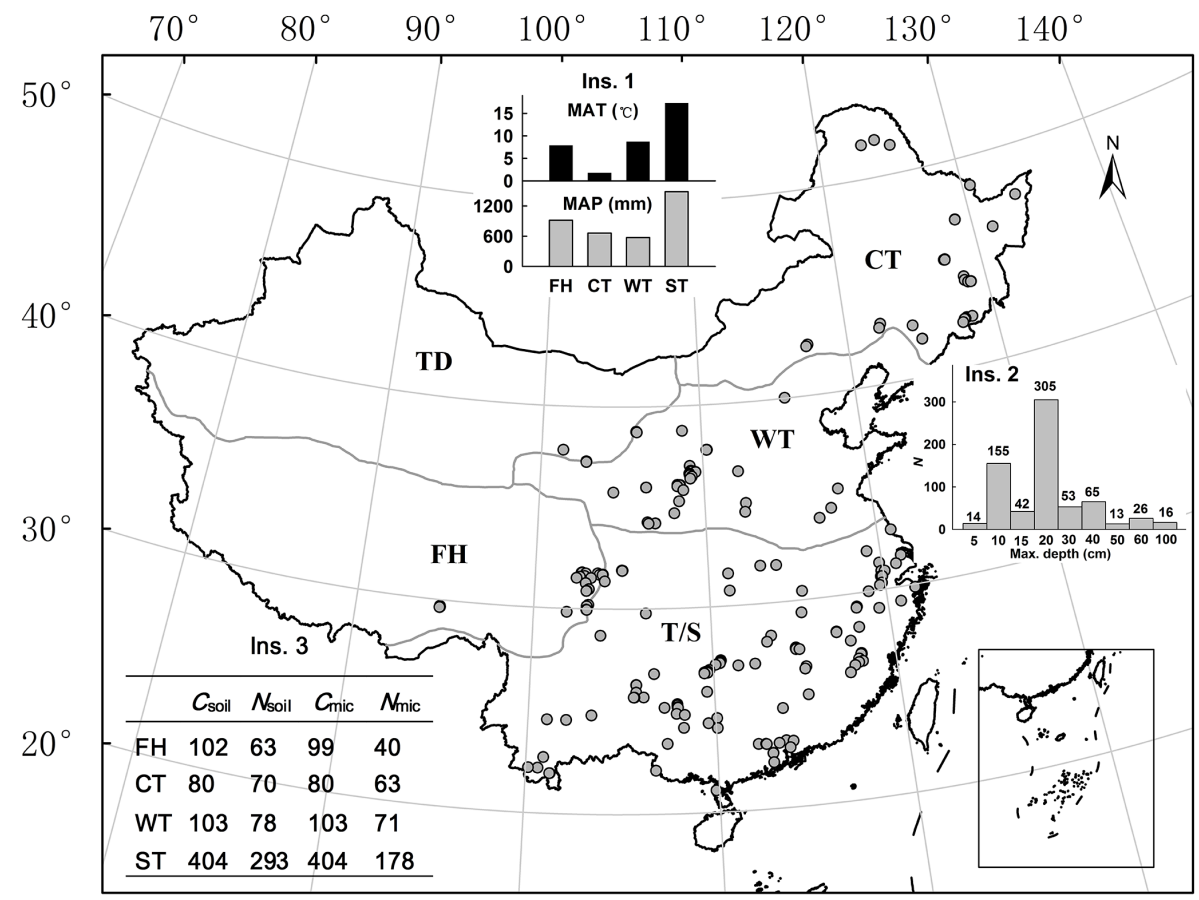

Figure 1. A map of China showing the distribution of sampling sites and data summary for this synthesis. The climate zones are categorized following Wu (1988) into frigid highland (FH), cool temperate (CT), warm temperate (WT), subtropical/tropical (ST), and temperate desert (TD) zones. The TD is excluded in the synthesis, because forests are rarely distributed in the zone. Inset 1: mean annual temperature (MAT) and mean annual precipitation (MAP) by climate zones. Inset 2: frequency distribution of maximum depth of soil sampling. Inset 3: the number of measurements of soil organic carbon $\left(\mathrm{C}_{\text {soil }}\right)$, soil total nitrogen $\left(\mathrm{N}_{\text {soil }}\right)$, microbial biomass carbon $\left(\mathrm{C}_{\text {mic }}\right)$, and microbial biomass nitrogen $\left(\mathrm{N}_{\mathrm{mic}}\right)$ by climate zones.

(e.g., Tian et al., 2010) that averaged the climate data across the whole climate zones for many years, the MAT and MAP in this study were calculated from the original literature and weighted by the numbers of measurements. This algorithm may more realistically reflect the environmental conditions driving the microbial metabolism, because microbial communities are more directly responsive to the local habitat, rather than the large-scaled environment. All data collected in this study were numerical data from the tables, text, or extracted from the figures in the original papers with the Origin 7.0 digital plugin (Digitize; OriginLab Ltd., China).

\subsection{Data standardization and analyses}

Considering the effects of climate, parent materials and vegetation, we standardized the data set by implementing the following procedures. First, we categorized the data set into five climate zones, i.e., frigid highland (FH), cool temperate (CT), warm temperate (WT), temperate desert (TD), and subtropical/tropical (ST) zones based on the 1:1000 000 landuse map of China (Wu, 1988). Since forests are rarely distributed in the TD zone, we excluded it in this synthesis (Fig. 1). Second, we further divided the forests within each climate zone into natural and planted forests by management regimes. Third, the soil data were all standardized to the top
$20 \mathrm{~cm}$ depth in order to maximize the cross-study comparison. The rationales for doing this are: (1) $\mathrm{C}_{\mathrm{mic}}$ and $\mathrm{N}_{\text {mic }}$ are concentrated on the top soil layers $(0-20 \mathrm{~cm}$; Cleveland and Liptzin, 2007); and (2) direct comparisons with the raw data are problematic, because the individual studies included in the current data set applied different soil sampling methods (e.g., by soil profile horizons or fixed-depth layers) and sampling depths. About $75 \%$ of the studies were implicated in the top $20 \mathrm{~cm}$ of the soil (Fig. 1 Inset 2). Therefore, we conducted the following procedures for the topsoil standardization: (1) in the cases that the $0-20 \mathrm{~cm}$ topsoil was divided into more than one sublayer, we obtained the bulk density (BD) weighted means of $\mathrm{C}_{\text {soil }}, \mathrm{N}_{\text {soil }}, \mathrm{C}_{\text {mic }}$, and $\mathrm{N}_{\text {mic }}$ across the $0-20 \mathrm{~cm}$ depth. The BD, if missing in the original papers, was derived from an empirical relationship between SOM and $\mathrm{BD}$ (i.e., $\mathrm{BD}=0.29+1.2033 \exp (-0.0775 \times \mathrm{SOM})$; Wu et al., 2003; Yang et al., 2007). (2) In the cases that the maximum sampling depth was less than $20 \mathrm{~cm}$, we estimated the $\mathrm{C}_{\text {soil }}, \mathrm{N}_{\text {soil }}, \mathrm{C}_{\text {mic }}$, and $\mathrm{N}_{\text {mic }}$ across the $0-20 \mathrm{~cm}$ depth with the empirical equations $\left(\mathrm{C}_{\text {soil }}: y=1-0.878 x, R^{2}=0.95, P\right.$ $<0.001 ; \mathrm{N}_{\mathrm{soil}}: y=1-0.893 x, R^{2}=0.95, P<0.001 ; \mathrm{C}_{\mathrm{mic}}$ : $y=1-0.889 x, R^{2}=0.97, P<0.001 ; \mathrm{N}_{\text {mic }}: y=1-0.869 x$, $R^{2}=0.97, P<0.001$, where $x$ is the soil depth $(\mathrm{cm})$, and $y$ is the cumulative fraction of the dependent variable. See details in Fig. S1 in the Supplement). (3) In the cases that the 


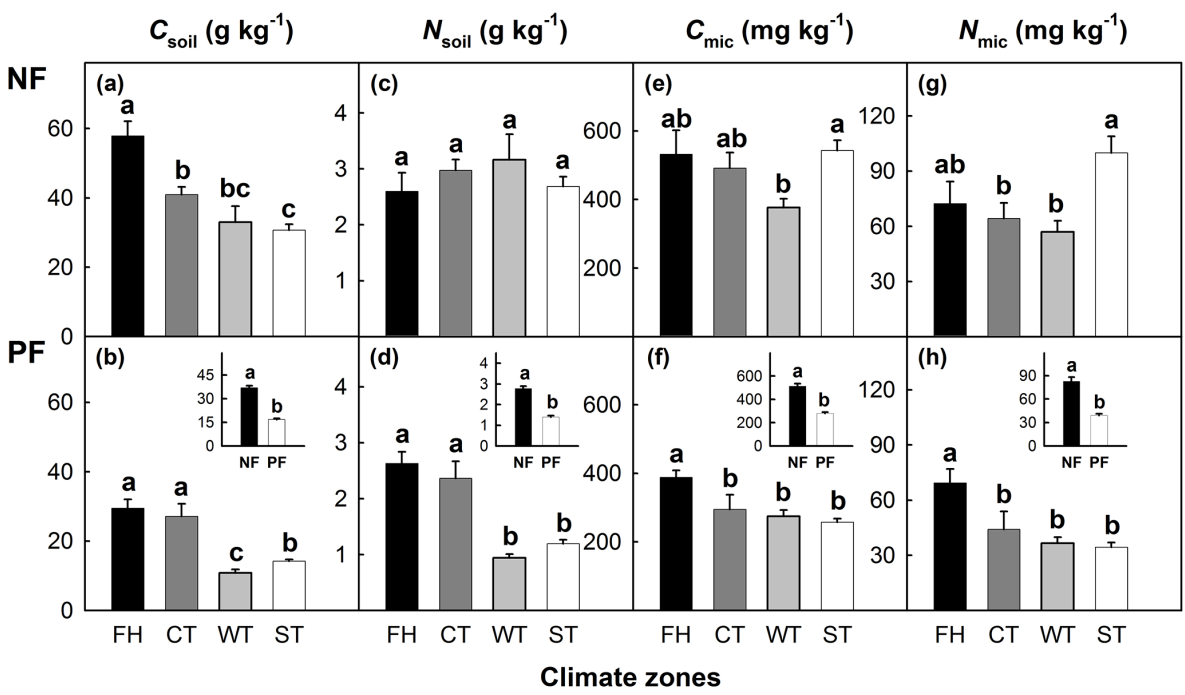

Figure 2. Comparisons of $\mathrm{C}_{\mathrm{soil}}(\mathbf{a}, \mathbf{b}), \mathrm{N}_{\text {soil }}(\mathbf{c}, \mathbf{d}), \mathrm{C}_{\mathrm{mic}}(\mathbf{e}, \mathbf{f})$, and $\mathrm{N}_{\text {mic }}(\mathbf{g}, \mathbf{h})$ among climate zones and between management regimes. Inserted figures are the overall comparisons between the natural (NF) and planted forests (PF). $\mathrm{C}_{\text {soil }}, \mathrm{N}_{\text {soil }}, \mathrm{C}_{\text {mic }}$, and $\mathrm{N}_{\text {mic }}$ stand for soil organic carbon, soil total nitrogen, microbial biomass carbon, and microbial biomass nitrogen, respectively. FH, CT, WT, and ST stand for frigid highland zone, cool temperate zone, warm temperate zone, and subtropical/tropical zone, respectively. Different lowercase letters denote significant differences among the climate zones or between the management regimes (mean $\pm \mathrm{SE}, \alpha=0.05$ ).

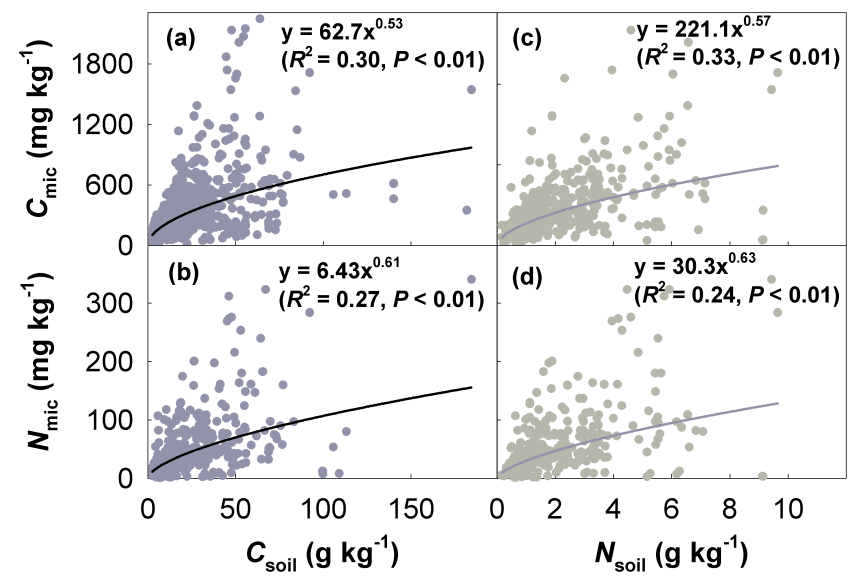

Figure 3. Relationships between soil resources and microbial biomass. $\mathrm{C}_{\text {soil }}, \mathrm{N}_{\text {soil }}, \mathrm{C}_{\text {mic }}$, and $\mathrm{N}_{\text {mic }}$ stand for soil organic carbon, soil total nitrogen, microbial biomass carbon, and microbial biomass nitrogen, respectively. The regression models are given.

seasonal dynamics in microbial biomass were reported, we calculated arithmetic means of the data.

An ANOVA procedure was performed to test the differences in all variables among climate zones and between management regimes. A multiple regression procedure was employed to examine the effects of soil resources and climate on $\mathrm{C}_{\text {mic }}, \mathrm{N}_{\text {mic }}, \mathrm{C}_{\text {mic }}: \mathrm{N}_{\text {mic }}$ ratio and microbial quotient. A full model (including the independent variables of both soil resources and climate and possible interactions) and a reduced model (only including the independent variables of soil re-

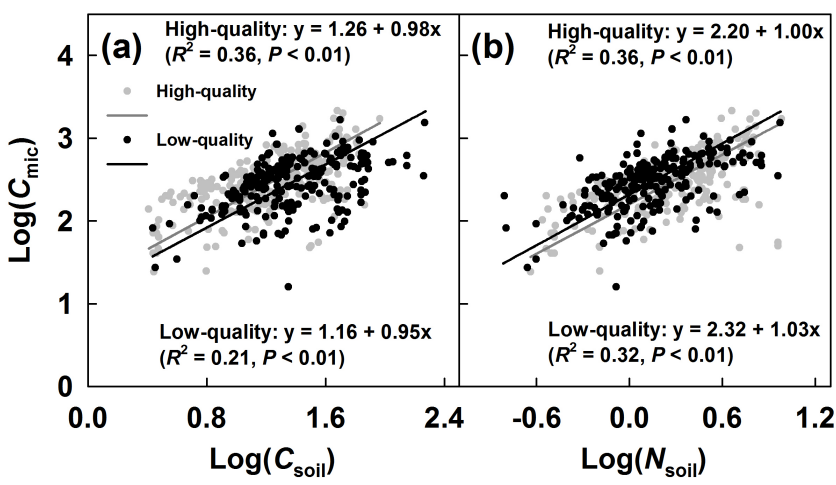

Figure 4. Relationships between microbial biomass carbon $\left(\mathrm{C}_{\mathrm{mic}}\right)$ and soil organic carbon $\left(\mathrm{C}_{\text {soil }}, \mathbf{a}\right)$, and soil total nitrogen $\left(\mathrm{N}_{\text {soil }}, \mathbf{b}\right)$ by two soil quality groups: high-quality group $\left(\mathrm{C}_{\text {soil }}: \mathrm{N}_{\text {soil }}\right.$ ratio $\leq$ the median of the whole data set, $n=251$ ) vs. low-quality group $\left(\mathrm{C}_{\text {soil }}: \mathrm{N}_{\text {soil }}\right.$ ratio $>$ the median, $n=250$; See details in the Methods). Log stands for 10-based logarithm. The standardized major axis (SMA) models are given for each group.

sources and possible interactions) for each dependent variable were developed to examine partial contributions of soil resources or climate to the variability. A backward elimination procedure was conducted to remove insignificant terms $(\alpha=0.05)$ in the models. The variables, if needed, were transformed with a 10-based logarithm to meet the assumptions of normality and homoscedasticity for the regressions.

To examine the effect of soil quality on $\mathrm{C}_{\mathrm{mic}}$, we subjectively divided the original data set into two groups by the median of the $\mathrm{C}_{\text {soil }}: \mathrm{N}_{\text {soil }}$ ratio, and defined as high- 
Table 1. Multiple regression models of microbial biomass carbon $\left(\mathrm{C}_{\text {mic }}\right)$, microbial biomass nitrogen $\left(\mathrm{N}_{\text {mic }}\right), \mathrm{C}_{\text {mic }}: \mathrm{N}_{\text {mic }}$ ratio, and microbial quotients (i.e., $\mathrm{C}_{\text {mic }} / \mathrm{C}_{\text {soil }}$ and $\mathrm{N}_{\text {mic }} / \mathrm{N}_{\text {soil }}$ rates) against soil resources and climate. $\mathrm{C}_{\text {soil }}$ and $\mathrm{N}_{\text {soil }}$ stand for soil organic carbon and soil total nitrogen, respectively. $Y, X_{1}, X_{2}, X_{3}, X_{4}, X_{5}$ in the models stand for the dependent variable, $\mathrm{C}_{\text {soil }}, \mathrm{N}_{\text {soil }}$, mean annual temperature, mean annual precipitation, and $\mathrm{C}_{\text {soil }}: \mathrm{N}_{\text {soil }}$ ratio, respectively. $Y, X_{1}$ and $X_{2}$ are 10-based $\log \operatorname{transformed} . N, R^{2}, P$ stand for sample size, determination coefficient, and probability, respectively. All the terms in the regression models are significant at $\alpha=0.05$.

\begin{tabular}{|c|c|c|c|c|c|c|c|c|}
\hline \multirow[b]{2}{*}{$\begin{array}{l}\text { Dependent } \\
\text { variable }\end{array}$} & \multicolumn{4}{|l|}{ Reduced model } & \multicolumn{4}{|l|}{ Full model } \\
\hline & $\begin{array}{l}\text { Independent variables } \\
\text { of soil resources }\end{array}$ & $N$ & $R^{2}$ & $P$ & $\begin{array}{l}\text { Independent variables } \\
\text { of soil resources and climate }\end{array}$ & $N$ & $R^{2}$ & $P$ \\
\hline $\mathrm{C}_{\mathrm{mic}}$ & $\begin{array}{l}Y=1.19+2.02 X_{1}-0.850 X_{1}^{2} \\
-1.31 X_{2}-1.08 X_{2}^{2}+1.67 X_{1} \times X_{2}\end{array}$ & 501 & 0.366 & $<0.001$ & $\begin{array}{l}Y=2.27+0.206 X_{1}-0.706 X_{2}^{2}+0.493 X_{1} \times X_{2}+1.75 \\
\times 10^{-2} X_{3}-5.40 \times 10^{-4} X_{4}+1.67 \times 10^{-7} X_{4}^{2}\end{array}$ & 501 & 0.392 & $<0.001$ \\
\hline $\mathrm{N}_{\text {mic }}$ & $Y=1.51-1.14 X_{2}^{2}+0.752 X_{1} \times X_{2}$ & 338 & 0.287 & $<0.001$ & $\begin{array}{l}Y=0.643+0.421 X_{1}-0.626 X_{2}-1.19 X_{2}^{2}+0.984 X_{1} \times X_{2} \\
+6.72 \times 10^{-2} X_{3}+1.29 \times 10^{-7} X_{4}^{2}-3.89 \times 10^{-5} X_{3} \times X_{4}\end{array}$ & 338 & 0.407 & $<0.001$ \\
\hline $\mathrm{C}_{\mathrm{mic}}: \mathrm{N}_{\mathrm{mic}}$ & $\begin{array}{l}Y=0.956+0.578 X_{2}+0.528 X_{2}^{2} \\
-0.640 X_{1} \times X_{2}-7.53 \times 10^{-3} X_{5}\end{array}$ & 335 & 0.108 & $<0.001$ & $\begin{array}{l}Y=1.24+0.759 X_{2}+0.659 X_{2}^{2}-0.843 X_{1} \times X_{2}-4.72 \\
\times 10^{-2} X_{3}+1.06 \times 10^{-3} X_{3}^{2}+1.01 \times 10^{-5} X_{3} \times X_{4}-1.25 \times 10^{-2} X_{5}\end{array}$ & 335 & 0.244 & $<0.001$ \\
\hline $\mathrm{C}_{\text {mic }} / \mathrm{C}_{\text {soil }}$ & $\begin{array}{l}Y=4.13-0.982 X_{1}^{2}-1.22 X_{2} \\
-1.99 X_{2}^{2}+2.39 X_{1} \times X_{2}\end{array}$ & 501 & 0.367 & $<0.001$ & $\begin{array}{l}Y=4.12-0.858 X_{1}^{2}-1.38 X_{2}-2.01 X_{2}^{2}+2.38 X_{1} \times X_{2} \\
-5.06 \times 10^{-4} X_{4}+2.46 \times 10^{-5} X_{3} \times X_{4}\end{array}$ & 501 & 0.391 & $<0.001$ \\
\hline $\mathrm{N}_{\text {mic }} / \mathrm{N}_{\text {soil }}$ & $\begin{array}{l}Y=-3.68+14.3 X_{1}-9.17 X_{1}^{2}-15.2 X_{2} \\
-10.3 X_{2}^{2}+18.8 X_{1} \times X_{2}+0.205 X_{5}\end{array}$ & 338 & 0.173 & $<0.001$ & $\begin{array}{l}Y=-4.02+13.1 X_{1}-8.73 X_{1}^{2}-15.3 X_{2}-10.9 X_{2}^{2} \\
+19.2 X_{1} \times X_{2}+0.141 X_{3}-2.55 \times 10^{-3} X_{3}^{2}-2.80 \times 10^{-5} X_{3} \\
\times X_{4}+0.223 X_{5}\end{array}$ & 338 & 0.306 & $<0.001$ \\
\hline
\end{tabular}

quality group $\left(\mathrm{C}_{\text {soil }}: \mathrm{N}_{\text {soil }}\right.$ ratio $\leq$ the median, $\left.n=251\right)$ and low-quality group $\left(\mathrm{C}_{\text {soil }}: \mathrm{N}_{\text {soil }}\right.$ ratio $>$ the median, $\left.n=250\right)$. Then we applied the standardized major axis (SMA) procedure to compare the $\mathrm{C}_{\text {mic }}-\mathrm{C}_{\text {soil }}$ or $\mathrm{C}_{\text {mic }}-\mathrm{N}_{\text {soil }}$ relationship between the two groups. The SMA procedure was also used to compare the $\mathrm{C}_{\text {mic }}: \mathrm{N}_{\text {mic }}-\mathrm{C}_{\text {soil }}: \mathrm{N}_{\text {soil }}$ relationship between this study and the one derived from the global data set (Cleveland and Liptzin, 2007). All statistical analyses were performed with SPSS 19.0 for Windows; and the map (Fig. 1) was generated with ArcGIS 10.

\section{Results}

\subsection{Concentrations of soil microbial biomass carbon and nitrogen}

By synthesized 689 measurements on soil microbial biomass carbon $\left(\mathrm{C}_{\mathrm{mic}}\right)$ and nitrogen $\left(\mathrm{N}_{\text {mic }}\right)$ from 207 independent studies published up to November 2014 across China's forest ecosystems, we found that the $C_{\text {mic }}$ in the topsoil $(0-20 \mathrm{~cm})$ varied by 142 folds (mean \pm SD: $390.2 \pm 312.9 \mathrm{~g} \mathrm{~kg}^{-1}$ ), the $\mathrm{N}_{\text {mic }}$ varied by 289 folds $\left(60.1 \pm 57.4 \mathrm{~g} \mathrm{~kg}^{-1}\right), \mathrm{C}_{\text {soil }}$ varied by 72 folds $\left(26.2 \pm 21.9 \mathrm{~g} \mathrm{~kg}^{-1}\right)$, and the $\mathrm{N}_{\text {soil }}$ varied by 62 folds $\left(2.06 \pm 1.65 \mathrm{~g} \mathrm{~kg}^{-1}\right)$. The $\mathrm{C}_{\text {mic }}$ and $\mathrm{N}_{\text {mic }}$ differed significantly between management regimes and among climate zones (Fig. 2). The natural forests had significantly greater $\mathrm{C}_{\text {mic }}\left(514.1 \mathrm{mg} \mathrm{kg}^{-1}\right.$ vs. $\left.281.8 \mathrm{mg} \mathrm{kg}^{-1}\right)$ and $\mathrm{N}_{\text {mic }}$ $\left(82.6 \mathrm{mg} \mathrm{kg}^{-1}\right.$ vs. $\left.39.0 \mathrm{mg} \mathrm{kg}^{-1}\right)$ than the planted forests. In the natural forests, the $\mathrm{C}_{\text {mic }}$ and $\mathrm{N}_{\text {mic }}$ displayed similar patterns across the climate zones: $\mathrm{ST}>\mathrm{FH}>\mathrm{CT}>\mathrm{WT}$ (Fig. 2e and g). The $\mathrm{ST}$ zone had the greatest $\mathrm{C}_{\text {mic }}$ and $\mathrm{N}_{\text {mic }}$ with the greatest MAT and MAP (Fig. 1 Inset 1) in spite of having the least $\mathrm{C}_{\text {soil }}$ and $\mathrm{N}_{\text {soil }}$ among the climate zones (Fig. 2a and c). The $\mathrm{C}_{\text {soil }}$ significantly $(P<0.05)$ decreased from cold humid FH zone to warm humid ST zone, the former was one fold greater than the latter (Fig. 2a). This pattern was largely op- posite to that of MAT (Fig. 1 Inset 1). There was no significant difference in $\mathrm{N}_{\text {soil }}(P=0.673)$ among the climate zones $\left(2.83 \pm 1.85 \mathrm{~g} \mathrm{~kg}^{-1}\right.$; Fig. $\left.2 \mathrm{c}\right)$.

The planted forests had significantly lower concentrations of $\mathrm{C}_{\text {soil }}, \mathrm{N}_{\text {soil }}, \mathrm{C}_{\text {mic }}$, and $\mathrm{N}_{\text {mic }}$ than the natural forests $(P<0.05)$; the latter had 2.2, 2.0, 1.8, and 2.1 times as much as the former, respectively (Fig. 2 Inset). Unlike the natural forests, the planted forests exhibited relatively consistent patterns of $\mathrm{C}_{\text {soil }}, \mathrm{N}_{\text {soil }}, \mathrm{C}_{\text {mic }}$, and $\mathrm{N}_{\text {mic }}$ across the climate zones: $\mathrm{FH}>\mathrm{CT}>\mathrm{WT}$ or ST (Fig. 2b, d, f, and h).

The $\mathrm{C}_{\text {soil }}, \mathrm{N}_{\text {soil }}$, and their interactions explained $36.6 \%$ of the variability in $\mathrm{C}_{\text {mic }}$, and $28.7 \%$ in $\mathrm{N}_{\text {mic }}$; MAT and MAP explained additional 2.6 and $12.0 \%$, respectively (Table 1). Both $\mathrm{C}_{\mathrm{mic}}$ and $\mathrm{N}_{\text {mic }}$ were increasing in a power function with $\mathrm{C}_{\text {soil }}$ or $\mathrm{N}_{\text {soil }}$ (Fig. 3). Further SMA analysis showed that the high-quality (i.e., low $\mathrm{C}_{\text {soil }}: \mathrm{N}_{\text {soil }}$ ratio) and lowquality (i.e., high $\mathrm{C}_{\text {soil }}: \mathrm{N}_{\text {soil }}$ ratio) soil groups had a common slope $(P>0.05)$ of the $\log \left(\mathrm{C}_{\text {soil }}\right)-\log \left(\mathrm{C}_{\text {mic }}\right)$ or $\log \left(\mathrm{N}_{\text {soil }}\right)$ $-\log \left(\mathrm{C}_{\text {mic }}\right)$ relationship (Fig. 4). However, the high-quality group had a significantly greater intercept $(P<0.001)$ than the low-quality group for the $\log \left(\mathrm{C}_{\text {soil }}\right)-\log \left(\mathrm{C}_{\text {mic }}\right)$ relationship (Fig. 4a), while the former had a significantly less intercept $(P<0.001)$ than the latter for the $\log \left(\mathrm{N}_{\text {soil }}\right)-\log \left(\mathrm{C}_{\text {mic }}\right)$ relationship (Fig. 4b).

\subsection{Stoichiometry of soil microbial biomass carbon and nitrogen}

The $\mathrm{C}_{\text {soil }}: \mathrm{N}_{\text {soil }}$ and $\mathrm{C}_{\text {mic }}: \mathrm{N}_{\text {mic }}$ ratios varied by 15 folds $(13.7 \pm 6.63)$ and 41 folds $(8.25 \pm 6.20)$ across the country, respectively. Management regime and climate zone significantly affected the $\mathrm{C}_{\text {mic }}: \mathrm{N}_{\text {mic }}$ ratio (Fig. 5). The $\mathrm{C}_{\text {mic }}: \mathrm{N}_{\text {mic }}$ ratio in the natural forests was significantly less $(P<0.05)$ than that in the planted forests (7.3 vs. 9.2; Fig. 5d Inset), while the $\mathrm{C}_{\text {soil }}: \mathrm{N}_{\text {soil }}$ ratio in the former was significantly greater $(P<0.05)$ than that in the latter $(15.2$ vs. $12.4 ;$ Fig. $5 \mathrm{~b}$ Inset). The $C_{\text {mic }}: \mathrm{N}_{\text {mic }}$ ratio showed a similar pattern across 


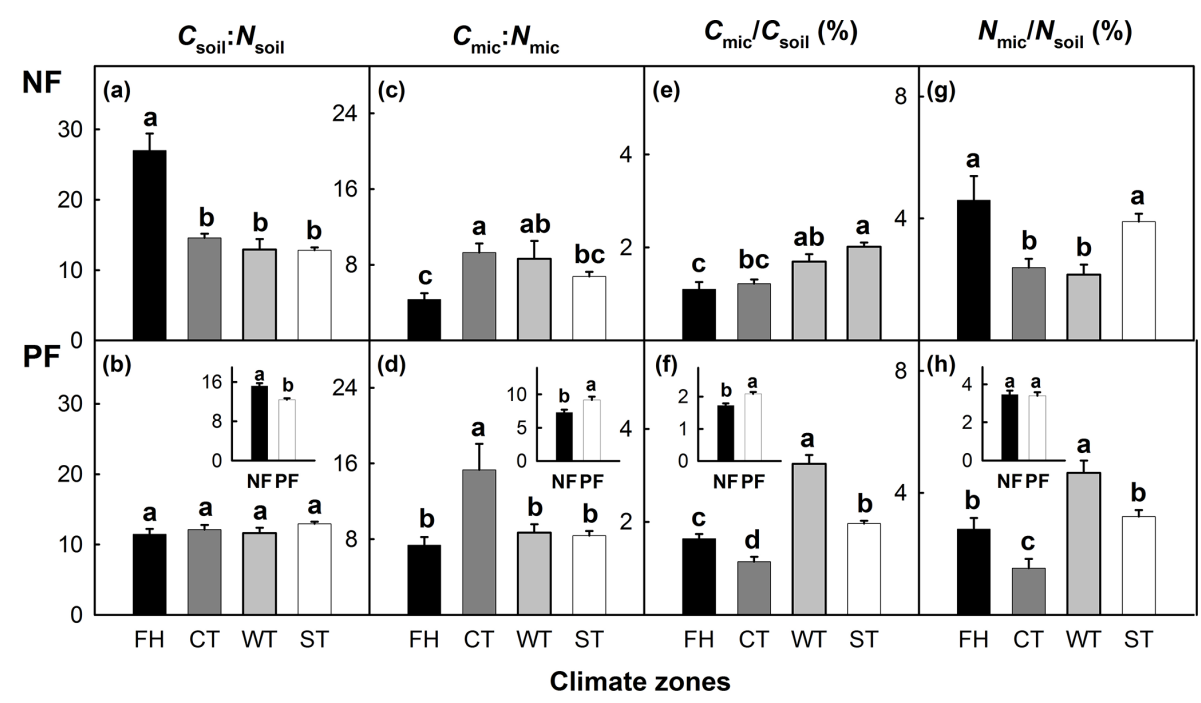

Figure 5. Comparisons of $\mathrm{C}_{\text {soil }}: \mathrm{N}_{\text {soil }}$ ratio (a, b), $\mathrm{C}_{\text {mic }}: \mathrm{N}_{\text {mic }}$ ratio (c, d), $\mathrm{C}_{\text {mic }} / \mathrm{C}_{\text {soil }}$ rate (e, f), and $\mathrm{N}_{\text {mic }} / \mathrm{N}_{\text {soil }}$ rate $(\mathbf{g}, \mathbf{h})$ among climate zones and between management regimes. Inserted figures are overall comparisons between the natural (NF) and planted forests (PF). $\mathrm{C}_{\text {soil }}, \mathrm{N}_{\text {soil }}, \mathrm{C}_{\mathrm{mic}}$, and $\mathrm{N}_{\text {mic }}$ stand for soil organic carbon, soil total nitrogen, microbial biomass carbon, and microbial biomass nitrogen, respectively. FH, CT, WT, and ST stand for frigid highland zone, cool temperate zone, warm temperate zone, and subtropical / tropical zone, respectively. Different lowercase letters denote significant differences among climate zones or between management regimes (mean $\pm S E$, $\alpha=0.05)$.

the climate zones for both natural and planted forests, with the greatest ratio occurring in the CT zone and the smallest ratio in the $\mathrm{FH}$ zone (Fig. 5c and d).

Pooling the data across the climate zones and management regimes, we found a significant power relationship, rather than a linear, between $\mathrm{C}_{\text {soil }}$ and $\mathrm{N}_{\text {soil }}$ or between $\mathrm{C}_{\text {mic }}$ and $\mathrm{N}_{\text {mic }}\left(P<0.001\right.$; Fig. S2). The $\mathrm{C}_{\text {soil }}$ and $\mathrm{N}_{\text {soil }}$ together explained $10.8 \%$ of the variability in the $\mathrm{C}_{\text {mic }}: \mathrm{N}_{\text {mic }}$ ratio, and climate explained another $13.6 \%$ (Table 1). There was a weak negative correlation between $\mathrm{C}_{\text {mic }}: \mathrm{N}_{\text {mic }}$ ratio and $\mathrm{C}_{\text {soil }}$ : $\mathrm{N}_{\text {soil }}$ ratio $\left(n=335, P<0.01, R^{2}=0.04\right.$; Fig. 6a), which was consistent with the relationship derived from the global data set (Cleveland and Liptzin, 2007). The slopes of the relationships were $-0.13[-0.21,-0.05]$ (mean [95\% confidence interval]) from this study and $-0.12[-0.23$, $-0.01]$ from the global data set, while the intercepts were 9.73 [8.45, 11.06] and 9.34 [7.86, 10.82], respectively. The $\mathrm{C}_{\text {mic }}: \mathrm{N}_{\text {mic }}$ ratio increased with latitude (Fig. $6 \mathrm{~b}$ ), decreased with MAT (Fig. 6c), and was correlated with MAP in a quadratic polynomial function (Fig. 6d).

\subsection{Soil microbial quotient}

The $\mathrm{C}_{\text {mic }} / \mathrm{C}_{\text {soil }}$ rate varied by 91 folds $(1.92 \% \pm 1.17 \%)$ across China's forest ecosystems, while the $\mathrm{N}_{\text {mic }} / \mathrm{N}_{\text {soil }}$ rate varied by 480 folds $(3.43 \% \pm 2.49 \%)$. They differed significantly between management regimes and among climate zones (Fig. 5). The $\mathrm{C}_{\text {mic }} / \mathrm{C}_{\text {soil }}$ rate in the natural forests was significantly less $(P<0.05)$ than that in the planted forests ( $1.7 \%$ vs. $2.1 \%$; Fig. $5 f$ Inset), while the $\mathrm{N}_{\text {mic }} / \mathrm{N}_{\text {soil }}$ rate did not differ (3.5\% vs. $3.4 \% ; P>0.05$; Fig. 5 h Inset). The $\mathrm{C}_{\text {mic }} / \mathrm{C}_{\text {soil }}$ and $\mathrm{N}_{\text {mic }} / \mathrm{N}_{\text {soil }}$ rates showed different patterns across the climate zones between the natural and planted forests (Fig. 5e-h). In the natural forests, the FH zone had the least $\mathrm{C}_{\text {mic }} / \mathrm{C}_{\text {soil }}$ rate but the greatest $\mathrm{N}_{\text {mic }} / \mathrm{N}_{\text {soil }}$ rate among the climate zones; the $\mathrm{ST}$ zone had greater $\mathrm{C}_{\text {mic }} / \mathrm{C}_{\text {soil }}$ and $\mathrm{N}_{\text {mic }} / \mathrm{N}_{\text {soil }}$ rates (Fig. 5e and g). In the planted forests, the $\mathrm{C}_{\text {mic }} / \mathrm{C}_{\text {soil }}$ and $\mathrm{N}_{\text {mic }} / \mathrm{N}_{\text {soil }}$ rates showed similar patterns across the climate zones: WT $>\mathrm{ST}>\mathrm{FH}>\mathrm{CT}$ (Fig. $5 \mathrm{f}$ and h).

The $\mathrm{C}_{\text {soil }}, \mathrm{N}_{\text {soil }}$, and their combinations explained $36.7 \%$ of the variability in the $\mathrm{C}_{\text {mic }} / \mathrm{C}_{\text {soil }}$ rate, and $17.3 \%$ in the $\mathrm{N}_{\text {mic }} / \mathrm{N}_{\text {soil }}$ rate; MAT, MAP, and their interactions explained another 2.4 and $13.3 \%$, respectively (Table 1 ). The $\mathrm{C}_{\text {mic }} / \mathrm{C}_{\text {soil }}$ rate decreased in a power function with the $\mathrm{C}_{\text {soil }}$ : $\mathrm{N}_{\text {soil }}$ ratio (Fig. 7a), but the $\mathrm{N}_{\text {mic }} / \mathrm{N}_{\text {soil }}$ rate increased linearly with the $\mathrm{C}_{\text {soil }}: \mathrm{N}_{\text {soil }}$ ratio (Fig. $7 \mathrm{~b}$ ). Both $\mathrm{C}_{\text {mic }} / \mathrm{C}_{\text {soil }}$ and $\mathrm{N}_{\text {mic }} / \mathrm{N}_{\text {soil }}$ rates increased with MAT (Fig. $7 \mathrm{c}$ and d). There was a quadratic polynomial function between the $\mathrm{C}_{\text {mic }} / \mathrm{C}_{\text {soil }}$ rate and MAP (Fig. 7e), but there was no significant relationship $(P>0.05)$ between the $\mathrm{N}_{\text {mic }} / \mathrm{N}_{\text {soil }}$ rate and MAP (Fig. 7f).

\section{Discussion}

\subsection{Variability in forest soil microbial biomass carbon and nitrogen}

The $\mathrm{C}_{\text {mic }}$ and $\mathrm{N}_{\text {mic }}$ in China's forest ecosystems varied substantially with climate zones and management regimes (CV up to $80-96 \%$ ), consistent with previous studies (Cleveland 


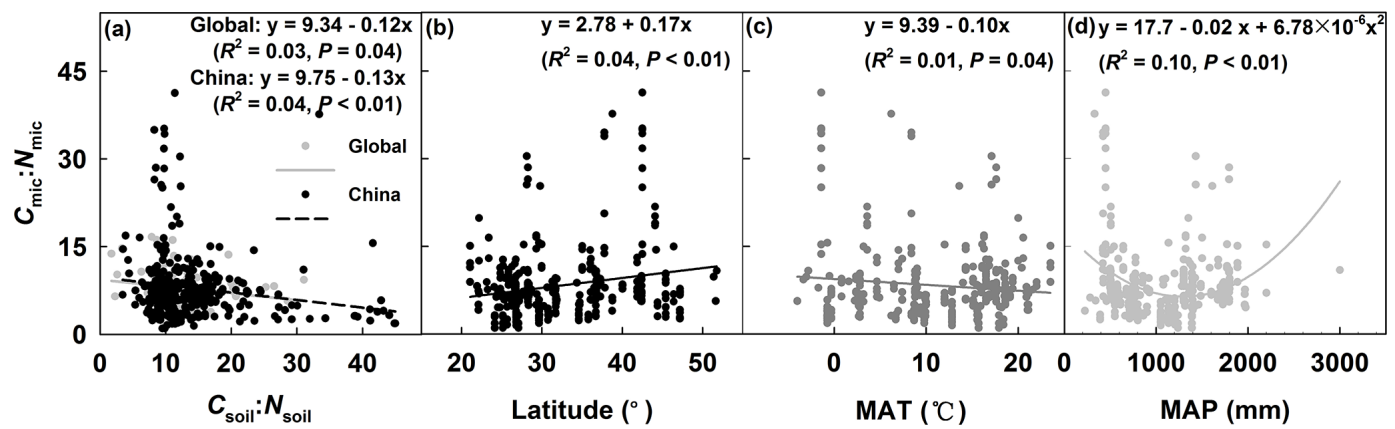

Figure 6. Relationships between $\mathrm{C}_{\text {mic }}: \mathrm{N}_{\text {mic }}$ and $\mathrm{C}_{\text {soil }}: \mathrm{N}_{\text {soil }}$ ratios (China: from this study vs. Globe: from Cleveland \& Liptzin, 2007; a), latitude (b), MAT (c), and MAP (d), respectively. $\mathrm{C}_{\text {soil }}, \mathrm{N}_{\text {soil }}, \mathrm{C}_{\mathrm{mic}}, \mathrm{N}_{\mathrm{mic}}$, MAT, and MAP stand for soil organic carbon, soil total nitrogen, microbial biomass carbon, microbial biomass nitrogen, mean annual temperature, and mean annual precipitation, respectively. The regression models are given.

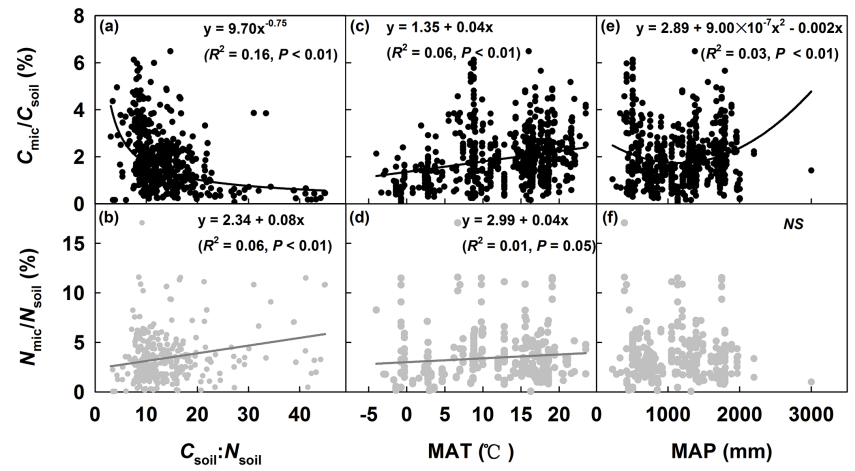

Figure 7. Relationships between $\mathrm{C}_{\text {mic }} / \mathrm{C}_{\text {soil }}$ or $\mathrm{N}_{\text {mic }} / \mathrm{N}_{\text {soil }}$ rate and $\mathrm{C}_{\text {soil }}: \mathrm{N}_{\text {soil }}$ ratio $(\mathbf{a}, \mathbf{b})$, MAT $(\mathbf{c}, \mathbf{d})$, and $\operatorname{MAP}(\mathbf{e}, \mathbf{f})$, respectively. $\mathrm{C}_{\text {soil }}, \mathrm{N}_{\text {soil }}, \mathrm{C}_{\text {mic }}, \mathrm{N}_{\text {mic }}$, MAT, and MAP stand for soil organic carbon, soil total nitrogen, microbial biomass carbon, microbial biomass nitrogen, mean annual temperature, and mean annual precipitation, respectively. The regression models are given. NS stands for non-significant.

and Liptzin, 2007; Tian et al., 2010; Xu et al., 2013). Forest disturbances contain various regimes and histories, and thus increase the complexity of the microbial biomass pattern associated with climate (Holden and Treseder, 2013). In this synthesis, the natural forests in the subtropical/tropical zones with the greatest MAT and MAP (Fig. 1 Inset 1) had the greatest $\mathrm{C}_{\mathrm{mic}}$ and $\mathrm{N}_{\text {mic }}$ among the climate zones (Fig. 2), while the planted counterparts had the least $\mathrm{C}_{\text {mic }}$ and $\mathrm{N}_{\text {mic }}$ (Fig. 2f and h). Similarly, the planted forests in both warm and cool temperate zones had lower $\mathrm{C}_{\text {mic }}$ and $\mathrm{N}_{\text {mic }}$ than those in the frigid highland zone. These different patterns between the natural and planted forests may be associated with, in addition to climate, more afforestation and younger plantations in regions other than the frigid highland zone in China (Fang et al., 2012; Yang et al., 2014).
In this study, soil resources and climate together explained about $40 \%$ of the variability in microbial biomass, to which $\mathrm{C}_{\text {soil }}$ and $\mathrm{N}_{\text {soil }}$ contributed 71-93\% (Table 1). All power functions of microbial biomass against soil resources had exponents of less than one (Fig. 3), indicating that microbes grow rapidly with soil resource availability increasing when the $\mathrm{C}_{\text {soil }}$ or $\mathrm{N}_{\text {soil }}$ is low, but the acceleration decreases as the $\mathrm{C}_{\text {soil }}$ or $\mathrm{N}_{\text {soil }}$ increases. This implies a shift in constraints of microbial growth from resource availability to other abiotic and/or biotic factors, such as soil moisture, temperature, $\mathrm{pH}$, etc. Furthermore, the high-quality (i.e., low $\mathrm{C}_{\text {soil }}: \mathrm{N}_{\text {soil }}$ ratio) soils had a greater intercept of the $\log \left(\mathrm{C}_{\text {soil }}\right)-\log \left(\mathrm{C}_{\text {mic }}\right)$ relationship (Fig. 4a) but a less intercept of the $\log \left(\mathrm{N}_{\text {soil }}\right)$ $\log \left(\mathrm{C}_{\text {mic }}\right)$ relationship (Fig. $\left.4 \mathrm{~b}\right)$ than the low-quality soils. This result indicates that the microbes grow faster in the soils with a lower $\mathrm{C}_{\text {soil }}$ : $\mathrm{N}_{\text {soil }}$ ratio at a specific $\mathrm{C}_{\text {soil }}$ level or in the carbon-richer soils at a specific $\mathrm{N}_{\text {soil }}$. These findings illustrate that the relationships between soil resources and microbial biomass are affected by the availability and stoichiometry of $\mathrm{C}_{\text {soil }}$ and $\mathrm{N}_{\text {soil }}$.

\subsection{Stoichiometry of forest soil microbial biomass carbon and nitrogen}

The $\mathrm{C}_{\text {mic }}: \mathrm{N}_{\text {mic }}$ ratio in the topsoil for the natural forests in this study (7.3) is slightly greater than the global mean (6.9; Cleveland and Liptzin, 2007; Xu et al., 2013). It varied substantially less than $\mathrm{C}_{\mathrm{mic}}$ (41 folds vs. 142 folds) or $\mathrm{N}_{\text {mic }}$ (289 folds; Fig. 5). The relatively little variability in the $\mathrm{C}_{\text {mic }}: \mathrm{N}_{\text {mic }}$ ratio, together with its slight decline with the $\mathrm{C}_{\text {soil }}$ : $\mathrm{N}_{\text {soil }}$ ratio (Fig. 6a), illustrates that soil microbes alleviate soil resource stoichiometry (Kaiser et al., 2014), rather than "you are what you eat" (Sterner and Elser, 2002).

Nevertheless, the $\mathrm{C}_{\text {mic }}: \mathrm{N}_{\text {mic }}$ ratio decreased by $13 \%$ as the $\mathrm{C}_{\text {soil }}: \mathrm{N}_{\text {soil }}$ ratio increased (Fig. 6a), consistent with other terrestrial ecosystems studies (e.g., Cleveland and Liptzin, 2007; Fanin et al., 2013); And it also changed with latitude (Fig. 6b) and climate (Fig. 6c and d). Although the $R^{2}$ val- 
ues of these relationships were small, they reflect a general trend of the stoichiometric flexibility of the microbial communities (Sterner and Elser, 2002; Li et al., 2012; Fanin et al., 2013). Small adjustments of microbial biomass stoichiometry may have a significant effect on soil resource cycles (e.g., respiration and N, P mineralization, c.f., Mooshammer et al., 2014). Further multiple regression analysis showed that soil resources and climate together explained $24.4 \%$ of the variability in the $\mathrm{C}_{\text {mic }}: \mathrm{N}_{\text {mic }}$ ratio (Table 1), which might be useful for modeling the biogeochemical cycle of forest ecosystems. However, no conclusive notion has been reached on the underlying mechanisms of such an environmental plasticity of microbial stoichiometry. We speculate that the greater $\mathrm{C}_{\text {mic }}: \mathrm{N}_{\text {mic }}$ ratio in cold temperate zone (Figs. 1 Inset, $5 \mathrm{c}$, and d), perhaps similar to that in the plant leaves (He et al., 2006; Asner et al., 2014), might reflect an increased carbon investment on structural material (e.g., cell wall) as a defensive strategy in harsh environments. Additionally, environmental changes may shift microbial community composition, and thus change the $\mathrm{C}_{\mathrm{mic}}: \mathrm{N}_{\text {mic }}$ ratio (Drenovsky et al., 2010; Tischer et al., 2014), because fungi have higher $\mathrm{C}: \mathrm{N}$ ratio than bacteria (Keiblinger et al., 2010). Clearly, disclosing the underlying mechanisms of microbial metabolism is challenging but critically needed.

\subsection{Forest soil microbial quotient}

Soil microbial quotient is largely determined by microbial assimilation and respiration that are mainly affected by soil resources and environmental conditions (Manzoni et al., 2012). In this study, we found that $\mathrm{C}_{\text {mic }} / \mathrm{C}_{\text {soil }}$ and $\mathrm{N}_{\text {mic }} / \mathrm{N}_{\text {soil }}$ rates responded to soil resources differently or even oppositely. First, soil resources explained $36.7 \%$ of the variability in the $\mathrm{C}_{\text {mic }} / \mathrm{C}_{\text {soil }}$ but only $17.3 \%$ in the $\mathrm{N}_{\text {mic }} / \mathrm{N}_{\text {soil }}$ (Table 1 ), indicating that the $\mathrm{C}_{\text {mic }} / \mathrm{C}_{\text {soil }}$ rate was more controlled by soil resources. Second, the $\mathrm{C}_{\text {mic }} / \mathrm{C}_{\text {soil }}$ and $\mathrm{N}_{\text {mic }} / \mathrm{N}_{\text {soil }}$ rates responded oppositely to the $\mathrm{C}_{\text {soil }}: \mathrm{N}_{\text {soil }}$ ratio, i.e., decreasing in a power function (Fig. 7a) versus increasing linearly (Fig. 7b). Third, much stronger interactions between MAT and MAP exerted on the $\mathrm{N}_{\text {mic }} / \mathrm{N}_{\text {soil }}$ rate than the $\mathrm{C}_{\text {mic }} / \mathrm{C}_{\text {soil }}$ rate, because weak or no correlations between the $\mathrm{N}_{\text {mic }} / \mathrm{N}_{\text {soil }}$ rate and MAT (Fig. 7d) or MAP (Fig. 7f) despite that climate factors explained 4.5 times more variability in the $\mathrm{N}_{\text {mic }} / \mathrm{N}_{\text {soil }}$ rate than in the $\mathrm{C}_{\text {mic }} / \mathrm{C}_{\text {soil }}$ rate (13.3\% vs. $2.4 \%$; Table 1). These results, together with Fig. 4 (See the discussion above), suggest that soil microbial assimilation of carbon and nitrogen respond differently to soil resources and climate, and might be regulated by different mechanisms.

Vegetation and disturbances modify soil resources, interact with climate, and eventually affect microbial growth and metabolism (Figs. 5 and 7). The rapid decrease in $\mathrm{C}_{\text {mic }} / \mathrm{C}_{\text {soil }}$ rate with $\mathrm{C}_{\text {soil }}: \mathrm{N}_{\text {soil }}$ ratio increasing (Fig. 7a) suggests that soil microbes produce less biomass and respire more carbon in N-limited soils (Xu et al., 2014). The underlying mechanisms, however, are still not clear. Spohn (2015) sum- marized three potential mechanisms, i.e., microbial nitrogen mining, overflow respiration and enzyme inhibition at high nitrogen concentration. Additionally, microbial communities, in responses to changes in $\mathrm{C}_{\text {soil }}: \mathrm{N}_{\text {soil }}$ ratio, may evolve to a new balance between species-specific resource demand and resource availability in the micro-habitat via inter-specific competition and shifting of specific extracellular enzymes stoichiometry, and eventually alter the resource use efficiency at the community level (Tilman, 1982; Cherif and Loreau, 2007; Kaiser et al., 2014; Mooshammer et al., 2014; Torres et al., 2014).

\section{Conclusions}

By synthesizing 689 measurements from 207 independent studies across China's forest ecosystems, we find large variations in soil microbial biomass carbon and nitrogen and microbial quotient that are subjected to changes in soil resources, climate, and management regimes. We also provide evidence for stoichiometric flexibility of microbial communities. These results improve our understanding of soil microbial metabolic processes, ecological stoichiometry, and microbial responses to environmental change.

\section{The Supplement related to this article is available online at doi:10.5194/bg-12-6751-2015-supplement.}

Acknowledgements. We thank all the researchers whose data were used in this study and Anja Rammig and two anonymous reviewers for their valuable comments. This work was financially supported by the National Key Technology Research and Development Program of the Ministry of Science and Technology of China (no. 2011BAD37B01), the Program for Changjiang Scholars and Innovative Research Team in University (IRT_15R09), and the National Natural Science Funds (no. 30625010).

Edited by: A. Rammig

\section{References}

Asner, G. P., Martin, R. E., Tupayachi, R., Anderson, C. B., Sinca, F., Carranza-Jiménez, L., and Martinez, P.: Amazonian functional diversity from forest canopy chemical assembly, P. Natl. Acad. Sci. USA, 111, 5604-5609, 2014.

Bell, C., Carrillo, Y., Boot, C. M., Rocca, J. D., Pendall, E., and Wallenstein, M. D.: Rhizosphere stoichiometry: are C: N: P ratios of plants, soils, and enzymes conserved at the plant species level?, New Phytol., 201, 505-517, 2014.

Chapin III, F. S., Matson, P. A., and Vitousek, P. M.: Principles of Terrestrial Ecosystem Ecology, 2nd Edn., Springer, New York, $1-43,2011$. 
Cherif, M. and Loreau, M.: Stoichiometric constraints on resource use, competitive interactions, and elemental cycling in microbial decomposers, Am. Nat., 169, 709-724, 2007.

Cleveland, C. C. and Liptzin, D.: C: N: P stoichiometry in soil: is there a "Redfield ratio" for the microbial biomass?, Biogeochemistry, 85, 235-252, 2007.

Davidson, E. A. and Janssens, I. A.: Temperature sensitivity of soil carbon decomposition and feedbacks to climate change, Nature, 440, 165-173, 2006.

Drenovsky, R. E., Steenwerth, K. L., Jackson, L. E., and Scow, K. M.: Land use and climatic factors structure regional patterns in soil microbial communities, Global Ecol. Biogeogr., 19, 27-39, 2010.

Don A., Schumacher J., and Freibauer A.: Impact of tropical landuse change on soil organic carbon stocks-a meta-analysis, Glob. Chang Biol., 17, 1658-1670, 2011.

Edwards, K. A. and Jefferies, R. L.: Inter-annual and seasonal dynamics of soil microbial biomass and nutrients in wet and dry low-Arctic sedge meadows, Soil Biol. Biochem., 57, 83-90, 2013

Fang, J. Y., Shen, Z. H., Tang, Z. Y., Wang, X. P., Wang, Z. H., Feng, J. M., Liu, Y. N., Qiao, X. J., Wu, X. P., and Zheng, C. Y.: Forest community survey and the structural characteristics of forests in China, Ecography, 35, 1059-1071, 2012.

Fanin, N., Fromin, N., Buatois, B., and Hättenschwiler, S.: An experimental test of the hypothesis of non-homeostatic consumer stoichiometry in a plant litter - microbe system, Ecol. Lett., 16, 764-772, 2013

He, J. S., Fang, J. Y., Wang, Z. H., Guo, D. L., Flynn, D. F. B., and Geng, Z.: Stoichiometry and large-scale patterns of leaf carbon and nitrogen in the grassland biomes of China, Oecologia, 149, 115-122, 2006.

He, Y., Zhuang, Q., Harden, J. W., McGuire, A. D., Fan, Z., Liu, Y., and Wickland, K. P.: The implications of microbial and substrate limitation for the fates of carbon in different organic soil horizon types of boreal forest ecosystems: a mechanistically based model analysis, Biogeosciences, 11, 4477-4491, doi:10.5194/bg-114477-2014, 2014.

Holden, S. R. and Treseder, K. K.: A meta-analysis of soil microbial biomass responses to forest disturbances, Front. Microbiol., 4, 163, doi:10.3389/fmicb.2013.00163, 2013.

Jagadamma, S., Mayes, M. A., Steinweg, J. M., and Schaeffer, S. M.: Substrate quality alters the microbial mineralization of added substrate and soil organic carbon, Biogeosciences, 11, 46654678, doi:10.5194/bg-11-4665-2014, 2014.

Jandl, R., Lindner, M., Vesterdal, L., Bauwens, B., Baritz, R., Hagedorn, F., Johnson, D. W., Minkkinen, K., and Byrne, K. A.: How strongly can forest management influence soil carbon sequestration?, Geoderma, 137, 253-268, 2007.

Jefferies, R. L., Walker, N. A., Edwards, K. A., and Dainty, J.: Is the decline of soil microbial biomass in late winter coupled to changes in the physical state of cold soils?, Soil Biol. Biochem., 42, 129-135, 2010.

Kaiser, C., Fuchslueger, L., Koranda, M., Gorfer, M., Stange, C. F., Kitzler, B., Rasche, F., Strauss, J., Sessitsch, A., and Zechmeister-Boltenstern, S.: Plants control the seasonal dynamics of microbial $\mathrm{N}$ cycling in a beech forest soil by belowground C allocation, Ecology, 92, 1036-1051, 2011.
Kaiser, C., Franklin, O., Dieckmann, U., and Richter, A.: Microbial community dynamics alleviate stoichiometric constraints during litter decay, Ecol. Lett., 17, 680-690, 2014.

Keiblinger, K. M., Hall, E. K., Wanek, W., Szukics, U., Hämmerle, I., Ellersdorfer, G., Böck, S., Strauss, J., Sterflinger, K., and Richter, A.: The effect of resource quantity and resource stoichiometry on microbial carbon-use-efficiency, FEMS Microbiol. Ecol., 73, 430-440, 2010.

Li, Y., Wu, J. S., Liu, S. L., Shen, J. L., Huang, D.Y., Su, Y. R., Wei, W. X., and Syers, J. K.: Is the C:N:P stoichiometry in soil and soil microbial biomass related to the landscape and land use in southern subtropical China?, Global Biogeochem. Cy. 26, GB4002, doi:10.1029/2012GB004399, 2012.

Mann, L. K.: Changes in soil carbon storage after cultivation, Soil Sci., 142, 279-288, 1986.

Manzoni, S., Taylor, P., Richter, A., Porporato, A., and Ågren, G. I.: Environmental and stoichiometric controls on microbial carbonuse efficiency in soils, New Phytol., 196, 79-91, 2012.

Miltner, A., Bombach, P., Schmidt-Brücken, B., and Kästner, M.: SOM genesis: microbial biomass as a significant source, Biogeochemistry, 111, 41-55, 2012.

Mooshammer, M., Wanek, W., Zechmeister-Boltenstern, S., and Richter, A.: Stoichiometric imbalances between terrestrial decomposer communities and their resources: mechanisms and implications of microbial adaptations to their resources, Front. Microbiol., 5, 22, doi:10.3389/fmicb.2014.00022, 2014.

Paterson, E., Gebbing, T., Abel, C., Sim, A., and Telfer, G.: Rhizodeposition shapes rhizosphere microbial community structure in organic soil, New Phytol., 173, 600-610, 2007.

Singh, B. K., Bardgett, R. D., Smith, P., and Reay, D. S.: Microorganisms and climate change: terrestrial feedbacks and mitigation options, Nat. Rev. Microbiol., 8, 779-790, 2010.

Singh, J. S., Raghubanshi, A. S., Singh, R. S., and Srivastava, S. C.: Microbial biomass acts as a source of plant nutrients in dry tropical forest and savanna, Nature, 338, 499-500, 1989.

Sinsabaugh, R. L., Manzoni, S., Moorhead, D. L., and Richter, A.: Carbon use efficiency of microbial communities: stoichiometry, methodology and modelling, Ecol. Lett., 16, 930-939, 2013.

Sparling, G. P.: Ratio of microbial biomass carbon to soil organic carbon as a sensitive indicator of changes in soil organic matter, Soil Res., 30, 195-207, 1992.

Spohn, M.: Microbial respiration per unit microbial biomass depends on litter layer carbon-to-nitrogen ratio, Biogeosciences, 12, 817-823, doi:10.5194/bg-12-817-2015, 2015.

Sterner, R. W. and Elser, J. J.: Ecological stoichiometry: the biology of elements from molecules to the biosphere, Princeton University Press, Princeton, 8-16, 2002.

Tian, H. Q., Chen, G. S., Zhang, C., Melillo, J. M., and Hall, C. A. S.: Pattern and variation of $\mathrm{C}: \mathrm{N}: \mathrm{P}$ ratios in China's soils: a synthesis of observational data, Biogeochemistry, 98, 139-151, 2010.

Tilman, D.: Resource Competition and Community Structure. Monographs, Princeton University Press, Princeton, 1-16, 1982.

Tischer, A., Potthast, K., and Hamer, U.: Land-use and soil depth affect resource and microbial stoichiometry in a tropical mountain rainforest region of southern Ecuador, Oecologia, 175, 375-393, 2014.

Torres, I.F., Bastida, F., Hernández, T., Bombach, P., Richnow, H. H., and García, C.: The role of lignin and cellulose in the carbon- 
cycling of degraded soils under semiarid climate and their relation to microbial biomass, Soil Biol. Biochem., 75, 152-160, 2014.

Wang, C. K. and Yang, J. Y.: Rhizospheric and heterotrophic components of soil respiration in six Chinese temperate forests Glob. Change Biol., 13, 123-131, 2007.

Wardle, D. A.: A comparative assessment of factors which influence microbial biomass carbon and nitrogen levels in soil, Biol. Rev., 67, 321-358, 1992.

Wardle, D. A.: Controls of temporal variability in the soil microbial biomass: a global-scale synthesis, Soil Biol. Biochem., 30, 16271637, 1998.

Wu, C.: 1 : 1000000 Land Use Map of China. Science Press, Beijing, China, 1-80, 1988.

Wu, H. B., Guo, Z. T., and Peng, C. H.: Distribution and storage of soil organic carbon in China, Global Biogeochem. Cy., 17, 1048, doi:10.1029/2001GB001844, 2003.
Xu, X. F., Thornton, P. E., and Post, W. M.: A global analysis of soil microbial biomass carbon, nitrogen and phosphorus in terrestrial ecosystems, Glob. Ecol. Biogeogr., 22, 737-749, 2013.

Xu, X. F., Schimel, J. P., Thornton, P. E., Song, X., Yuan, F. M., and Goswami, S.: Substrate and environmental controls on microbial assimilation of soil organic carbon: a framework for Earth system models, Ecol. Lett., 17, 547-555, 2014.

Yang, Y. H., Mohammat, A., Feng, J. M., Zhou, R., and Fang, J. Y.: Storage, patterns and environmental controls of soil organic carbon in China, Biogeochemistry, 84, 131-141, 2007.

Yang, Y. H., Li, P., Ding, J. Z., Zhao, X., Ma, W. H., Ji, C. J., and Fang, J. Y.: Increased topsoil carbon stock across China's forests, Glob. Change Biol., 20, 2687-2696, 2014. 